\title{
Effects of acute and chronic administration of neurosteroid dehydroepiandrosterone sulfate on neuronal excitability in mice
}

This article was published in the following Dove Press journal:

Drug Design, Development and Therapy

21 March 2016

Number of times this article has been viewed

\author{
Dubravka Svob Strac' \\ Josipa Vlainic' \\ Janko Samardzic ${ }^{2}$ \\ Julija Erhardt ${ }^{3}$ \\ Zeljka Krsnik ${ }^{4}$
}

'Laboratory for Molecular Neuropsychiatry, Division of Molecular Medicine, Rudjer Boskovic Institute, Zagreb, Croatia; ${ }^{2}$ Institute of Pharmacology, Clinical Pharmacology and Toxicology, Medical Faculty, University of Belgrade, Belgrade, Serbia; ${ }^{3}$ Department of Animal Physiology, Faculty of Science, University of Zagreb, ${ }^{4}$ Croatian Institute for Brain Research, Department of Neuroscience, School of Medicine, University of Zagreb, Zagreb, Croatia
Correspondence: Dubravka Svob Strac Division of Molecular Medicine, Rudjer Boskovic Institute, Bijenicka cesta 54, 10000 Zagreb, Croatia

Tel +385 I 457 I268

$\mathrm{Fax}+385$ । 456 ।010

Email dsvob@irb.hr
Background: Neurosteroid dehydroepiandrosterone sulfate (DHEAS) has been associated with important brain functions, including neuronal survival, memory, and behavior, showing therapeutic potential in various neuropsychiatric and cognitive disorders. However, the antagonistic effects of DHEAS on $\gamma$-amino-butyric acid receptors and its facilitatory action on glutamatergic neurotransmission might lead to enhanced brain excitability and seizures and thus limit DHEAS therapeutic applications. The aim of this study was to investigate possible age and sex differences in the neuronal excitability of the mice following acute and chronic DHEAS administration.

Methods: DHEAS was administered intraperitoneally in male and female adult and old mice either acutely or repeatedly once daily for 4 weeks in a $10 \mathrm{mg} / \mathrm{kg}$ dose. To investigate the potential proconvulsant properties of DHEAS, we studied the effects of acute and chronic DHEAS treatment on picrotoxin-, pentylentetrazole-, and $N$-methyl-D-aspartate-induced seizures in mice. The effects of acute and chronic DHEAS administration on the locomotor activity, motor coordination, and body weight of the mice were also studied. We also investigated the effects of DHEAS treatment on $\left[{ }^{3} \mathrm{H}\right]$ flunitrazepam binding to the mouse brain membranes.

Results: DHEAS did not modify the locomotor activity, motor coordination, body weight, and brain $\left[{ }^{3} \mathrm{H}\right]$ flunitrazepam binding of male and female mice. The results failed to demonstrate significant effects of single- and long-term DHEAS treatment on the convulsive susceptibility in both adult and aged mice of both sexes. However, small but significant changes regarding sex differences in the susceptibility to seizures were observed following DHEAS administration to mice.

Conclusion: Although our findings suggest that DHEAS treatment might be safe for various potential therapeutic applications in adult as well as in old age, they also support subtle interaction of DHEAS with male and female hormonal status, which may underline observed sex differences in the relationship between DHEAS and various health outcomes.

Keywords: dehydroepiandrosterone sulfate, mice, age and sex differences, seizure threshold, motor activity, $\left[{ }^{3} \mathrm{H}\right]$ flunitrazepam binding

\section{Introduction}

Dehydroepiandrosterone sulfate (DHEAS) is a neurosteroid associated with various important functions in the mammalian brain. ${ }^{1-4}$ Namely, DHEAS has been reported to modulate neuronal plasticity, ${ }^{5-9}$ cognition, and emotions, ${ }^{10-15}$ thus showing therapeutic potential in a variety of neuropsychiatric and cognitive disorders. ${ }^{2,16-20}$ It appears that the effects of DHEAS in the central nervous system are mediated through its action on multiple signaling pathways and neurotransmitter systems, which are also involved in regulating the balance between excitation and inhibition in the brain..$^{3,15,21-23}$ Perhaps, the 
most documented has been the ability of DHEAS to bind and allosterically modulate the $\gamma$-amino-butyric acid $\left.{ }_{A}\left(G_{B A}\right)_{A}\right)$ receptor complex. ${ }^{3,15,21,24}$ In addition to its antagonistic effects on $\mathrm{GABA}_{\mathrm{A}}$ receptors, ${ }^{25-30}$ DHEAS has been shown to act as a positive modulator of $N$-methyl-D-aspartate (NMDA) receptors and facilitate NMDA-mediated glutamatergic neurotransmission through central sigma receptors. ${ }^{31,32}$

Some of these actions of DHEAS might lead to enhanced brain excitability and possible seizures ${ }^{33}$ and thus limit its potential therapeutic applications. Increase in the motor activity and body weight reduction may also appear consistently with potential proconvulsive, anxiogenic, and provoking effects of DHEAS. ${ }^{34,35}$ However, it is not yet fully elucidated to what extent DHEAS complex pharmacological profile contributes to its central actions, so the actual in vivo effects of DHEAS remain uncertain. Namely, in contrast to the reports suggesting that DHEAS can induce seizures when administered systemically or directly into the brain, ${ }^{35,36}$ other studies failed to confirm proconvulsant effects of DHEAS. ${ }^{37-41}$ Moreover, there is also a variety of data regarding the effects of DHEAS on the motor activity and body weight of the animals. ${ }^{34,37,42-45}$

Observed age-related decline in DHEAS levels suggests possible role of this neurosteroid in many disorders of aging. ${ }^{2,46,47}$ Low DHEAS levels have been associated with age-related changes and decreased lifespan in various animal studies, ${ }^{48}$ while exogenous DHEAS has been suggested to effectively ameliorate aging symptoms. ${ }^{49}$ However, the findings of some studies are inconsistent or negative.

Although observed beneficial effects of DHEAS, such as proimmune, antidiabetic, antiobesity, antiatherosclerosis, antiosteoporosis, anticarcinogenic, antidementia, antiaging, and many other effects, ${ }^{50,51}$ probably require rather long-term therapeutic strategy, so far most studies have investigated the effects of acute DHEAS treatment. ${ }^{15}$ Moreover, despite the knowledge that susceptibility to various mental disorders, including the sensitivity to seizures, ${ }^{52}$ as well as association between DHEAS and different health outcomes, ${ }^{53}$ often differ by sex, most preclinical studies of DHEAS were performed only in males.

Hence, given the chronic and age-related nature of many conditions for which DHEAS could be prescribed, as well as potential interaction of DHEAS with male and female hormonal status, ${ }^{42,54}$ we studied the effects of both acute and long-term DHEAS treatment in adult and aged mice of both sexes. Namely, in our study, we investigated possible age and sex differences in the susceptibility to seizures, as well as changes in locomotor activity, motor coordination, and body weight in mice following acute and chronic DHEAS administration.

In addition, sex differences in the seizure sensitivity might be due to the different modulation of the neurotransmitter receptor activity by DHEAS-derived sexual hormones and their metabolites. Therefore, we also studied the potential changes in the action of DHEAS at $\mathrm{GABA}_{\mathrm{A}}$ receptors using $\left[{ }^{3} \mathrm{H}\right]$ flunitrazepam binding on the brain membranes obtained from male and female mice following DHEAS treatment.

\section{Materials and methods}

\section{Animals}

Adult ( $\sim 3$ months old, weighing $20-25 \mathrm{~g}$ ) and aged ( $\sim 18$ months old, weighing 30-45 g) male and female CBA mice, bred in Rudjer Boskovic Institute, Zagreb, Croatia, were used. The animals were housed at a constant temperature $\left(22^{\circ} \mathrm{C}\right)$ and under a light cycle of 12-hour light/12-hour darkness (lights on at 7 am). Food and water were freely available. Mice were caged in groups of ten. As the female mice were caged next to the male mice, their estrus cycle was presumably synchronized due to the Whitten effect. ${ }^{55}$ All animal care and experimental procedures were carried out in accordance with the Directive 2010/63/EU of European Parliament and Council of the European Union on the protection of animals used for scientific purposes and the Croatian law on animal welfare. The ethical approval was obtained from Rudjer Boskovic Bioethics Committee.

\section{Drugs}

DHEAS (Aldrich Chemical Co, St Louis, Mo, USA), pentylenetetrazole (PTZ, Sigma-Aldrich Co., St Louis, MO, USA), picrotoxin (Sigma), and NMDA (Ascent Scientific, Bristol, UK) were dissolved in saline. Following the determination of animal body weight, DHEAS or saline was administered to mice intraperitoneally (ip) in a volume of $1 \mathrm{~mL}$ per 100 g body weight. In the acute experiments, $10 \mathrm{mg} / \mathrm{kg}$ DHEAS or saline was given 30 minutes prior to the animal testing. In the chronic experiments, mice were treated with DHEAS $(10 \mathrm{mg} / \mathrm{kg})$ or saline once daily for 4 consecutive weeks. The DHEAS dose was selected according to the literature data reporting that in mice, concentrations of dehydroepiandrosterone (DHEA/S) from 0.1 up to $1,200 \mathrm{mg} / \mathrm{kg}$ have been found to be active, while in the human studies, the administered doses range from 0.1 to $40 \mathrm{mg} / \mathrm{kg} / \mathrm{day}^{56}{ }^{5}$ The animal testing started 30 minutes following single (acute treatment) or the last (after 4 consecutive weeks of chronic treatment) DHEAS or saline administration. In addition to DHEAS, $\left[{ }^{3} \mathrm{H}\right]$ flunitrazepam (specific activity $96 \mathrm{Ci} / \mathrm{mmol}$, Amersham Biosciences Ltd, Buckinghamshire, UK) and diazepam (Sigma) dissolved 
in $0.1 \mathrm{~N} \mathrm{HCl}$ were used in radioligand binding studies on brain membranes, isolated from mice 30 minutes following DHEAS or saline administration.

\section{Locomotor activity measurement}

The locomotor activity measurements were performed between 8 am and $1 \mathrm{pm}$ in a quiet room under normal laboratory lighting. The horizontal ambulatory activity in individual mice was registered by Ugo-Basile Activity Cage. The activity was recorded for 10 minutes, starting after placing the animal into the test cage, 30 minutes following the single (acute treatment) or the last (after 4 consecutive weeks of chronic treatment) administration of DHEAS or saline. The observer left the room after placing the animal in the apparatus. The movements the animal makes inside the cage interrupted one or more infrared beam $/ \mathrm{s}$. The beam interruptions were counted, recorded by the electronic unit, and expressed as counts/10 minutes.

\section{Rota-rod test}

The motor coordination testing was also performed between 8 am and $1 \mathrm{pm}$ in a quiet room under normal laboratory lighting. Motor coordination was evaluated using a rota-rod test. Prior the experiment, all mice were tested in two 2-minute period sessions per 2 consecutive days on the rotating bar at a constant speed of $15 \mathrm{rpm}$. Only the animals with stable performance on the rotating rod were used in the experiment and tested again 30 minutes following the single (acute treatment) or the last (after 4 consecutive weeks of chronic treatment) administration of DHEAS or saline. Each mouse was placed on the rota-rod (Ugo-Basile Rota-rod Treadmill for mice, Ugo-Basile, Monvalle VA, Italy; speed of rod $15 \mathrm{rpm}$ ) and the number of falls and latency to fall were measured for up to 2 minutes.

\section{Seizure threshold determination}

All experiments regarding determination of proconvulsive activity were carried out between 8 am and 1 pm, 30 minutes following the single (acute treatment) or the last (after 4 consecutive weeks of chronic treatment) administration of DHEAS or saline. The animal was taken from its home cage and placed in a glass cylinder $\left(20 \times 7 \mathrm{~cm}^{2}\right)$ with numerous holes for ventilation, while its tail was drawn through a hole of the plastic cover and warmed for 1 minute under a tensor lamp. A butterfly infusion needle (length $20 \mathrm{~mm}$, gauge 27) was inserted into the tail vein, and correct placement was verified by the appearance of blood in the infusion tubing.

The convulsants acting on distinct ligand-gated ion

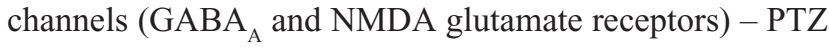

(4 $\mathrm{mg} / \mathrm{mL})$, picrotoxin $(0.75 \mathrm{mg} / \mathrm{mL})$, and NMDA $(8 \mathrm{mg} / \mathrm{mL})$ - were administered by constant intravenous (iv) infusion. The infusion rates, controlled by a microinfusion pump, were $1.1 \mathrm{~mL} / \mathrm{min}$ for PTZ and picrotoxin and $0.55 \mathrm{~mL} / \mathrm{min}$ for NMDA. During the convulsant infusion, the mouse was held lightly by the tip of the tail and observed, and the time between the start of infusion and the onset of seizures (latency) was recorded. Timed tail vein infusion provides qualitative assessments of several different convulsive responses, which occurred in progression and are divided into two categories: clonus indicates rapid rhythmic movements due to alternating contraction and relaxation of muscles, whereas tonus indicates rigidity due to contraction of muscles. ${ }^{57,58}$

For PTZ, the first convulsive sign was myoclonus (a sudden involuntary muscle jerk, usually accompanied by a head twitch), followed by running and bouncing clonus (violent whole-body clonus, including running and explosive jumps) and tonic hindlimb extension (characterized by extreme rigidity, with forelimbs and hindlimbs extended caudally). As myoclonic twitch was not observed consistently in all of the animals that were challenged with picrotoxin and NMDA, only two convulsive signs, running and bouncing clonus and tonic hindlimb extension, which reliably characterize picrotoxin- and NMDA-induced seizures, were reported. ${ }^{57}$ For each animal, the threshold dose of convulsant $(\mathrm{mg} / \mathrm{kg}$ of body weight) required to elicit particular convulsant sign was calculated from the time of infusion (latency), infusion rate, concentration of convulsant, and body weight.

\section{Preparation of the brain membranes}

The animals were sacrificed 30 minutes following the administration of DHEAS or saline. The mice forebrains were quickly isolated on ice, washed with ice-cold saline, and stored at $-20^{\circ} \mathrm{C}$. Brain membranes were prepared mainly as previously described. ${ }^{59}$ The frozen brains were homogenized in ice-cold $50 \mathrm{mM}$ Tris-citrate buffer $(\mathrm{pH}$ 7.4) and homogenates centrifuged at 47,000 rpm for 20 minutes at $4^{\circ} \mathrm{C}$. The pellet was washed in ice-cold $50 \mathrm{mM}$ Tris-citrate buffer ( $\mathrm{pH}$ 7.4), resuspended, and centrifuged three more times, than resuspended again and stored at $-20^{\circ} \mathrm{C}$. On the day of assay, the suspension was thawed, centrifuged once more at $20,000 \times g$ for 20 minutes at $4^{\circ} \mathrm{C}$ and used in $\left[{ }^{3} \mathrm{H}\right]$ flunitrazepam binding studies.

\section{$\left[{ }^{3} \mathrm{H}\right]$ Flunitrazepam binding assay}

For the $\left[{ }^{3} \mathrm{H}\right]$ flunitrazepam binding assay, aliquots of the brain membrane preparation $(\sim 100 \mathrm{mg}$ protein $/ \mathrm{mL})$ were incubated 
with $\left[{ }^{3} \mathrm{H}\right]$ flunitrazepam in $50 \mathrm{mM}$ Tris-citrate buffer (pH 7.4) containing $150 \mathrm{mM} \mathrm{NaCl}$ at $4^{\circ} \mathrm{C}$ for 90 minutes. Concentrations of DHEAS in the range from $1 \mu \mathrm{M}$ to $1 \mathrm{mM}$ were added to $1 \mathrm{nM}$ of $\left[{ }^{3} \mathrm{H}\right]$ flunitrazepam in inhibition studies. Nonspecific binding was determined in the presence of $100 \mu \mathrm{M}$ diazepam. In all binding assays, the total assay volume was $0.5 \mathrm{~mL}$. Each assay tube was run in duplicate. Radioactivity bound to membranes after vacuum filtration on Whatman GF/C filters was measured using $\beta$-scintillation counter (Wallace 1409 DSA, PerkinElmer Inc., Waltham, MA, USA).

\section{Protein concentration determination}

Protein content was determined in a $10 \mu \mathrm{L}$ sample, according to the method of Lowry et $\mathrm{al}^{60}$ using bovine serum albumin as a standard.

\section{Data analysis}

All results are expressed as mean values \pm standard error of the mean (SEM). The analysis and graphic presentation of data were performed using GraphPad Prism Version 4.00 for Windows (GraphPad Software Inc., La Jolla, CA, USA). Percentage change in $\left[{ }^{3} \mathrm{H}\right]$ flunitrazepam binding produced by DHEAS was defined as (specific binding in the presence of drug/specific binding in the absence of drug) $\times 100$. The inhibition curves were analyzed using the sigmoidal equation and the values of half-maximum and maximum inhibition of $\left[{ }^{3} \mathrm{H}\right]$ flunitrazepam binding produced by DHEAS were determined. Statistical analysis of the results was conducted by Student's $t$-test (for the comparison of two mean values) or by one-way analysis of variance (ANOVA). ANOVA was followed by the Newman-Keuls multiple comparison test. In animal testing, there were seven to eight animals per group, while data in binding studies were from three independent experiments performed in duplicate. $P$-values $<0.05$ were considered significant.

\section{Results}

\section{The effects of DHEAS treatment on the seizure threshold}

To investigate the possible proconvulsant activity of DHEAS in mice, we examined the effects of acute and chronic DHEAS administration on seizures induced by iv infusions of three different convulsants: pentylentetrazole, picrotoxin, and NMDA.

As shown in Figure 1, $10 \mathrm{mg} / \mathrm{kg}$ DHEAS administered acutely 30 minutes prior to iv infusion of convulsants failed to significantly affect the doses of noncompetitive GABA $_{\mathrm{A}}$ receptor antagonists pentylentetrazole (Figure 1A and B) and picrotoxin (Figure $1 \mathrm{C}$ and $\mathrm{D}$ ), as well as the doses of NMDA, an agonist of NMDA glutamate receptors (Figure 1E and F), needed to produce convulsive signs in the male as well as in the female adult mice. Even considerably higher doses of DHEAS (25 and $50 \mathrm{mg} / \mathrm{kg}$ ), administered acutely in animals of both sexes, have not produced any significant effects on the threshold of seizures induced by pentylentetrazole, picrotoxin, and NMDA (Table 1).

Because of the limited number of aged animals, we tested only the effects of acute DHEAS treatment on the picrotoxininduced seizures. DHEAS applied acutely in the dose of $10 \mathrm{mg} / \mathrm{kg}$ has not significantly modified the seizure reactivity of aged male (Figure 2A) as well as aged female mice to picrotoxin (Figure 2B), when compared to control group administered with saline.

Moreover, following chronic DHEAS $(10 \mathrm{mg} / \mathrm{kg})$ treatment, we observed no significant differences compared to control group in the doses of pentylentetrazole (Figure 3A and B), picrotoxin (Figure 3C and D), and NMDA (Figure 3E and $\mathrm{F}$ ) needed to induce clonic and tonic seizures in adult mice of both sexes.

\section{Sex and age differences in the seizure susceptibility following DHEAS treatment}

When control adult male and female mice were compared, significant differences were revealed in the doses of all three convulsants, required to elicit particular convulsant signs (Figure 4). Namely, in saline-treated animals, we observed significant sex differences in the clonic $(P<0.04$, Student's $t$-test) PTZ-induced seizures (Figure 4B), as well as in the tonic convulsions produced by picrotoxin $(P<0.002$, Student's $t$-test) (Figure 4E) and NMDA ( $P<0.001$, Student's $t$-test) (Figure 4G).

However, following DHEAS administration, we determined some discrete but significant changes regarding sex differences in the susceptibility to clonic seizures in comparison to control groups (Figure 4). Namely, as opposed to the control group, significant sex differences in the clonic PTZ-induced seizures were not observed in the adult mice treated acutely or chronically with $10 \mathrm{mg} / \mathrm{kg}$ of DHEAS (Figure 4B). These sex differences were not observed in the myoclonus (Figure 4A) or tonic seizures (Figure 4C), produced by PTZ, in saline- as well as in DHEAS-treated mice. On the other hand, significant differences $(P<0.04$, Student's $t$-test) between adult male and female mice were found in the dose of NMDA needed to produce clonic convulsions (Figure $4 \mathrm{~F}$ ) following chronic DHEAS $(10 \mathrm{mg} / \mathrm{kg}$ ) 

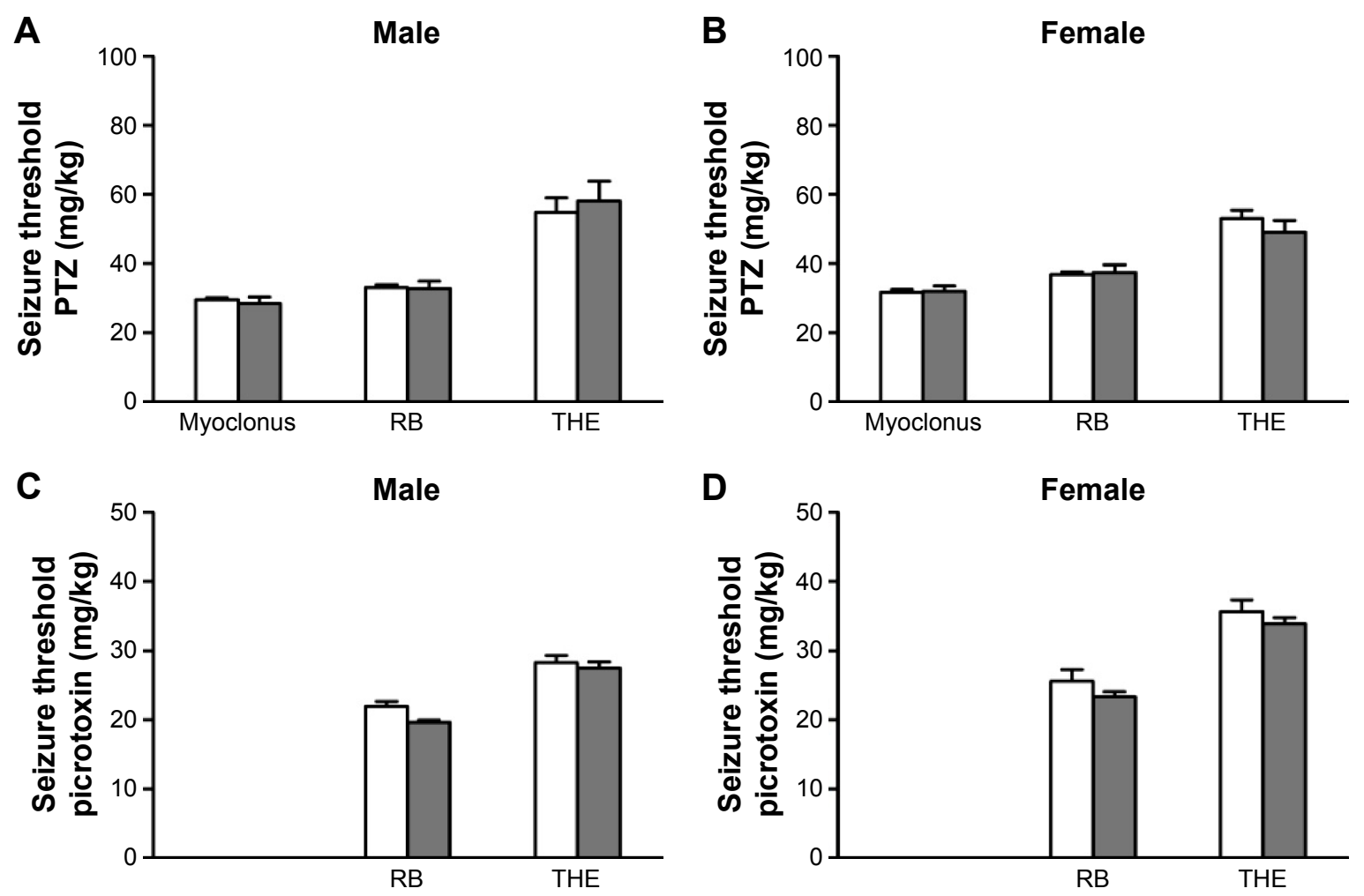

D
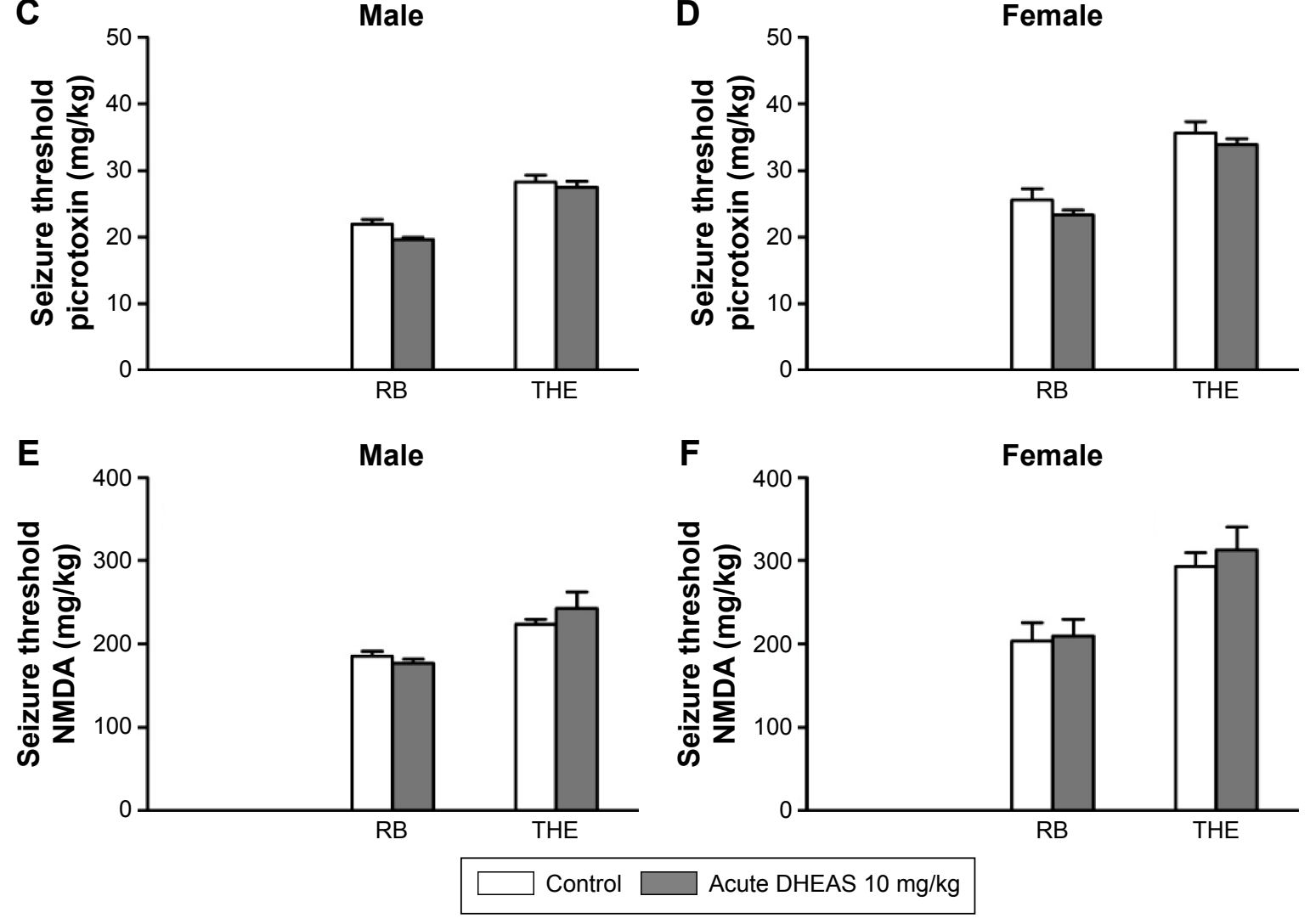

Female

Figure I The effects of acute DHEAS treatment on the seizure thresholds for ( $\mathbf{A}$ and $\mathbf{B}$ ) PTZ, (C and $\mathbf{D}$ ) picrotoxin, and (E and $\mathbf{F}$ ) NMDA in adult male and female mice. Notes: Saline (control group) or $10 \mathrm{mg} / \mathrm{kg}$ of DHEAS was administered intraperitoneally to mice 30 minutes prior to the intravenous infusion of convulsant. The observed convulsive signs - myoclonus, RB, and THE. The bars represent mean \pm SEM from seven to eight animals per group.

Abbreviations: DHEAS, dehydroepiandrosterone sulfate; NMDA, N-methyl-D-aspartate; PTZ, pentylenetetrazole; RB, running and bouncing clonus; SEM, standard error of the mean; THE, tonic hindlimb extension.

treatment, although these sex differences were not observed in control animals or mice treated with DHEAS acutely. In the case of threshold for tonic NMDA-induced seizures, significant differences between male and female mice were present in control, as well as in animals treated acutely and chronically with DHEAS (Figure 4G). In contrast to the saline-treated animals, after both acute $(P<0.002$, Student's $t$-test $)$ and chronic $(P<0.05$, Student's $t$-test) DHEAS treatment, significantly lower clonic picrotoxin-induced seizure thresholds were also found in adult male when compared to adult female mice (Figure 4D). However, as shown in Figure 4E, significant sex differences in the threshold of tonic seizures produced by picrotoxin were observed in both saline- and DHEAS-treated groups (acute and chronic treatment).

In aged mice, the findings regarding sex differences in the picrotoxin-induced seizure thresholds were opposite form the results obtained on adult mice (Table 2). Namely, in contrast to adult animals, when control aged male and female mice were compared, significant differences were 
Table I The effects of higher DHEAS doses $(25$ and $50 \mathrm{mg} / \mathrm{kg}$ ) on the seizure thresholds for PTZ, picrotoxin, and NMDA in adult male and female mice

\begin{tabular}{|c|c|c|c|}
\hline Seizure threshold & Myoclonus & RB & THE \\
\hline \multicolumn{4}{|l|}{ PTZ (mg/kg) } \\
\hline Control male mice & $29.59 \pm 0.58$ & $33.03 \pm 0.89$ & $52.90 \pm 3.41$ \\
\hline Control female mice & $31.67 \pm 0.79$ & $36.93 \pm 0.80$ & $53.06 \pm 2.40$ \\
\hline DHEAS-treated male mice $(25$ mg/kg) & $31.19 \pm 1.65$ & $34.69 \pm 1.97$ & $42.36 \pm 2.99$ \\
\hline DHEAS-treated female mice $(25$ mg/kg) & $29.50 \pm 2.60$ & $34.12 \pm 2.82$ & $46.33 \pm 4.29$ \\
\hline DHEAS-treated male mice $(50 \mathrm{mg} / \mathrm{kg})$ & $27.98 \pm 1.79$ & $31.21 \pm 2.10$ & $47.94 \pm 5.80$ \\
\hline DHEAS-treated female mice (50 mg/kg) & $31.04 \pm 1.81$ & $34.7 I \pm I .90$ & $43.53 \pm 1.60$ \\
\hline \multicolumn{4}{|l|}{ Picrotoxin (mg/kg) } \\
\hline Control male mice & - & $21.17 \pm 0.34$ & $28.28 \pm 0.98$ \\
\hline Control female mice & - & $25.62 \pm 1.62$ & $35.63 \pm 1.69$ \\
\hline DHEAS-treated male mice $(25$ mg/kg) & - & $19.01 \pm 0.66$ & $27.80 \pm 1.04$ \\
\hline DHEAS-treated female mice ( 25 mg/kg) & - & $23.66 \pm 0.64$ & $32.81 \pm 0.78$ \\
\hline DHEAS-treated male mice $(50 \mathrm{mg} / \mathrm{kg})$ & - & $19.57 \pm 0.50$ & $27.83 \pm 0.51$ \\
\hline DHEAS-treated female mice (50 mg/kg) & - & $23.52 \pm 0.30$ & $36.17 \pm 1.66$ \\
\hline \multicolumn{4}{|l|}{ NMDA (mg/kg) } \\
\hline Control male mice & - & $185.5 \pm 6.15$ & $223.8 \pm 6.09$ \\
\hline Control female mice & - & $203.6 \pm 22.31$ & $293.4 \pm 16.49$ \\
\hline DHEAS-treated male mice $(25 \mathrm{mg} / \mathrm{kg})$ & - & $194.9 \pm 8.26$ & $236.0 \pm 7.28$ \\
\hline DHEAS-treated female mice ( 25 mg/kg) & - & $191.8 \pm 3.95$ & $286.3 \pm 4.73$ \\
\hline DHEAS-treated male mice $(50 \mathrm{mg} / \mathrm{kg})$ & - & $|7| .6 \pm 5.9 \mid$ & $213.9 \pm 7.18$ \\
\hline DHEAS-treated female mice (50 mg/kg) & - & $222.4 \pm 8.43$ & $310.8 \pm 7.96$ \\
\hline
\end{tabular}

Notes: Saline (control group) and 25 and $50 \mathrm{mg} / \mathrm{kg}$ of DHEAS were administered intraperitoneally to mice 30 minutes prior to the intravenous infusion of convulsant. The observed convulsive signs - myoclonus, RB, and THE. The values represent mean \pm SEM from seven animals per group.

Abbreviations: DHEAS, dehydroepiandrosterone sulfate; NMDA, N-methyl-D-aspartate; PTZ, pentylenetetrazole; RB, running and bouncing clonus; SEM, standard error of the mean; THE, tonic hindlimb extension.

revealed in the doses of picrotoxin required to elicit clonic convulsive signs. On the other hand, in aged mice acutely treated with $10 \mathrm{mg} / \mathrm{kg}$ DHEAS, no significant sex differences were observed in clonic seizures produced by picrotoxin. In the case of picrotoxin-induced tonic convulsions, no sex differences were observed in aged mice treated acutely with saline or $10 \mathrm{mg} / \mathrm{kg}$ DHEAS, as opposed to the adult animals.

As shown in Table 2, the aged mice of both sexes demonstrated higher seizure sensitivity to picrotoxin when compared
A

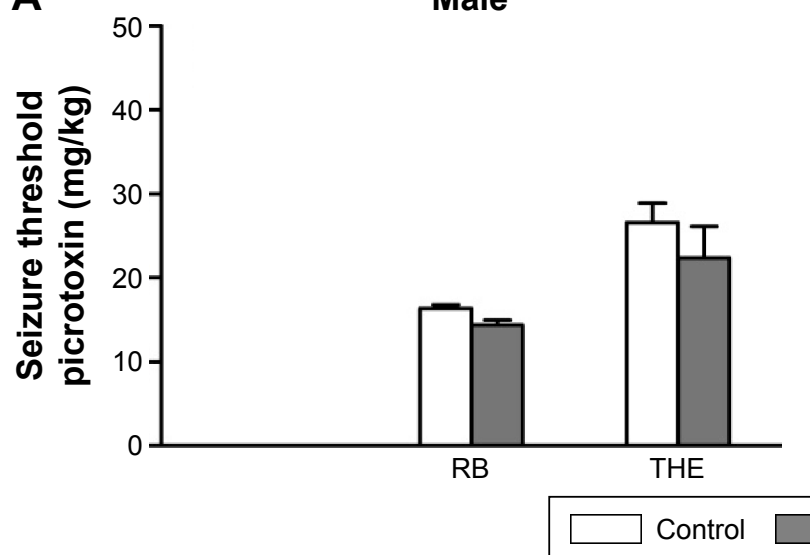

B

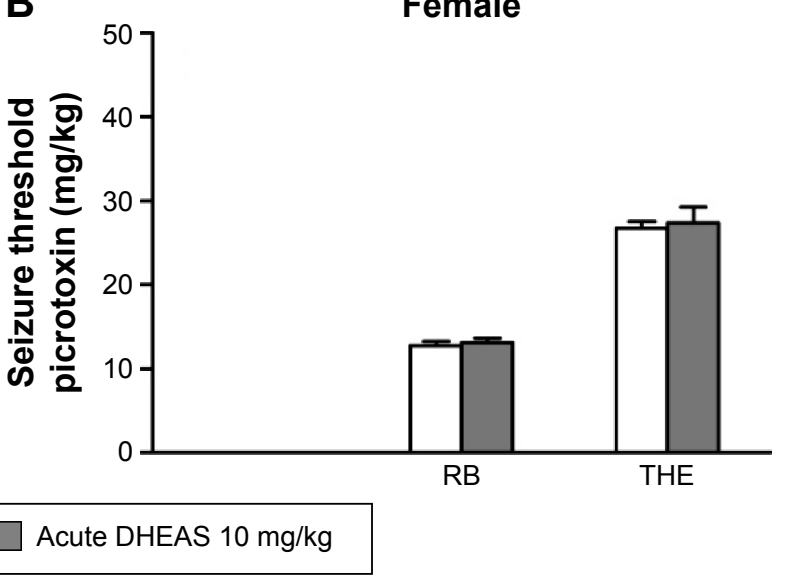

Figure 2 The effects of acute DHEAS treatment on the seizure thresholds for picrotoxin in aged (A) male and (B) female mice.

Notes: Saline (control group) or DHEAS $(10 \mathrm{mg} / \mathrm{kg}$ ) was administered intraperitoneally to mice 30 minutes prior to the intravenous infusion of picrotoxin. The observed convulsive signs $-\mathrm{RB}$ and THE. The bars represent mean \pm SEM from seven animals per group.

Abbreviations: DHEAS, dehydroepiandrosterone sulfate; RB, running and bouncing clonus; SEM, standard error of the mean; THE, tonic hindlimb extension. 

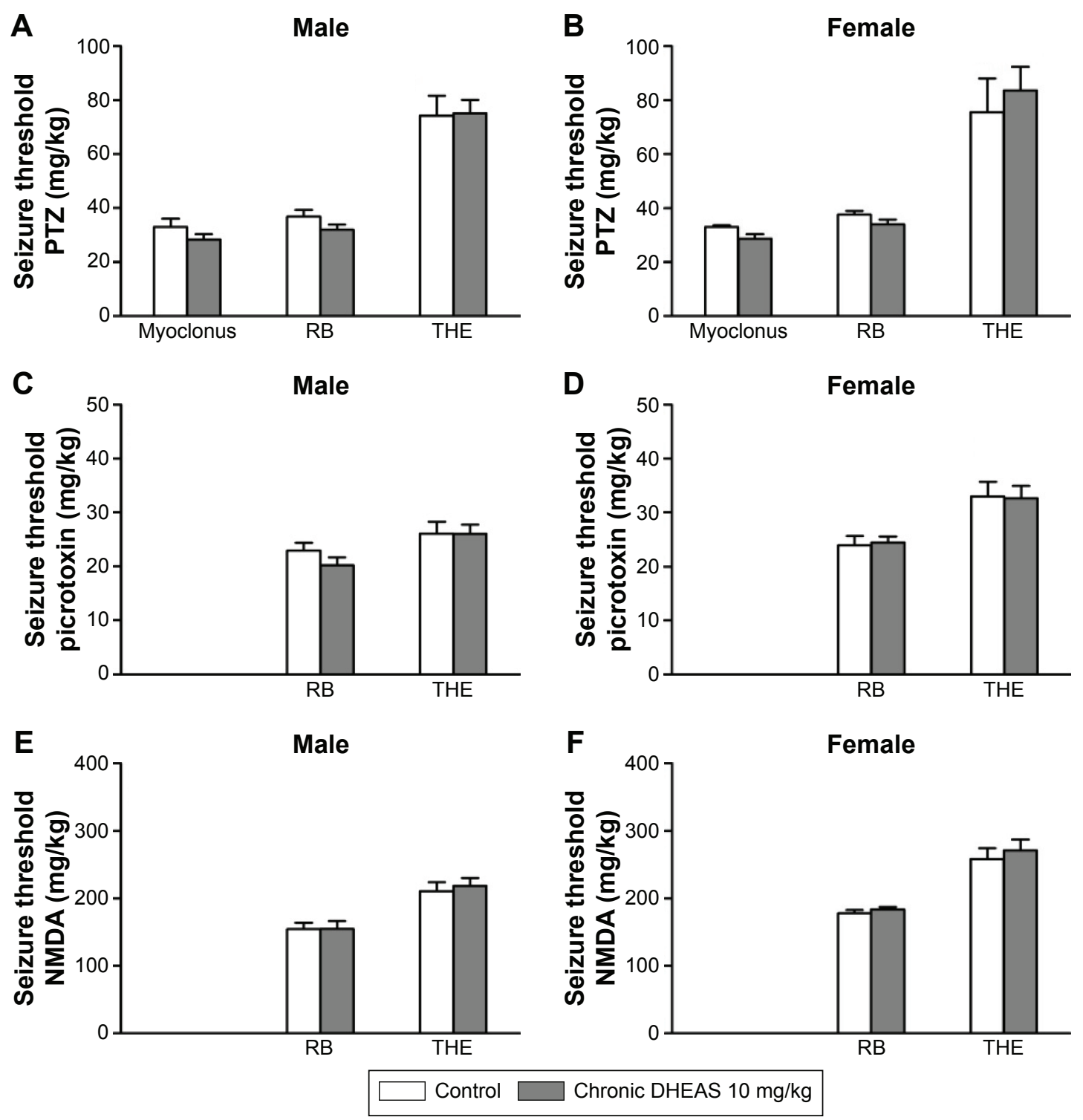

Figure 3 The effects of chronic DHEAS treatment on the seizure thresholds for (A and B) PTZ, (C and D) picrotoxin, and (E and F) NMDA in adult male and female mice. Notes: Saline (control group) or DHEAS (10 mg/kg) was administered intraperitoneally to adult mice once daily for 4 consecutive weeks. On the last day of chronic treatment, intravenous infusion of convulsant started 30 minutes following last DHEAS or saline administration. The observed convulsive signs - myoclonus, RB, and THE. The bars represent mean \pm SEM from seven to eight animals per group.

Abbreviations: DHEAS, dehydroepiandrosterone sulfate; NMDA, N-methyl-D-aspartate; PTZ, pentylenetetrazole; RB, running and bouncing clonus; SEM, standard error of the mean; THE, tonic hindlimb extension.

to adult mice, regardless of whether they were acutely treated with $10 \mathrm{mg} / \mathrm{kg}$ DHEAS or not. However, in the case of threshold for tonic convulsions, the age-related differences in male mice have not reached a level of significance.

\section{The effects of DHEAS treatment on the locomotor activity}

The results of ANOVA demonstrated that acute as well as chronic administration of $10 \mathrm{mg} / \mathrm{kg}$ DHEAS has not affected the number of counts measuring the movements produced by adult male or female mice during 10 minutes stay in the activity cage, suggesting unchanged locomotor activity of the adult animals of both sexes (Table 3 ).

\section{The effects of DHEAS treatment on the motor coordination}

As shown in Table 4, in experiments addressing the effect of acute and chronic $10 \mathrm{mg} / \mathrm{kg}$ DHEAS treatment on motor coordination, we observed no significant differences (ANOVA) in the number of falls and the latency to fall from the rota-rod treadmill between control- and DHEAS-treated adult male and female mice. 

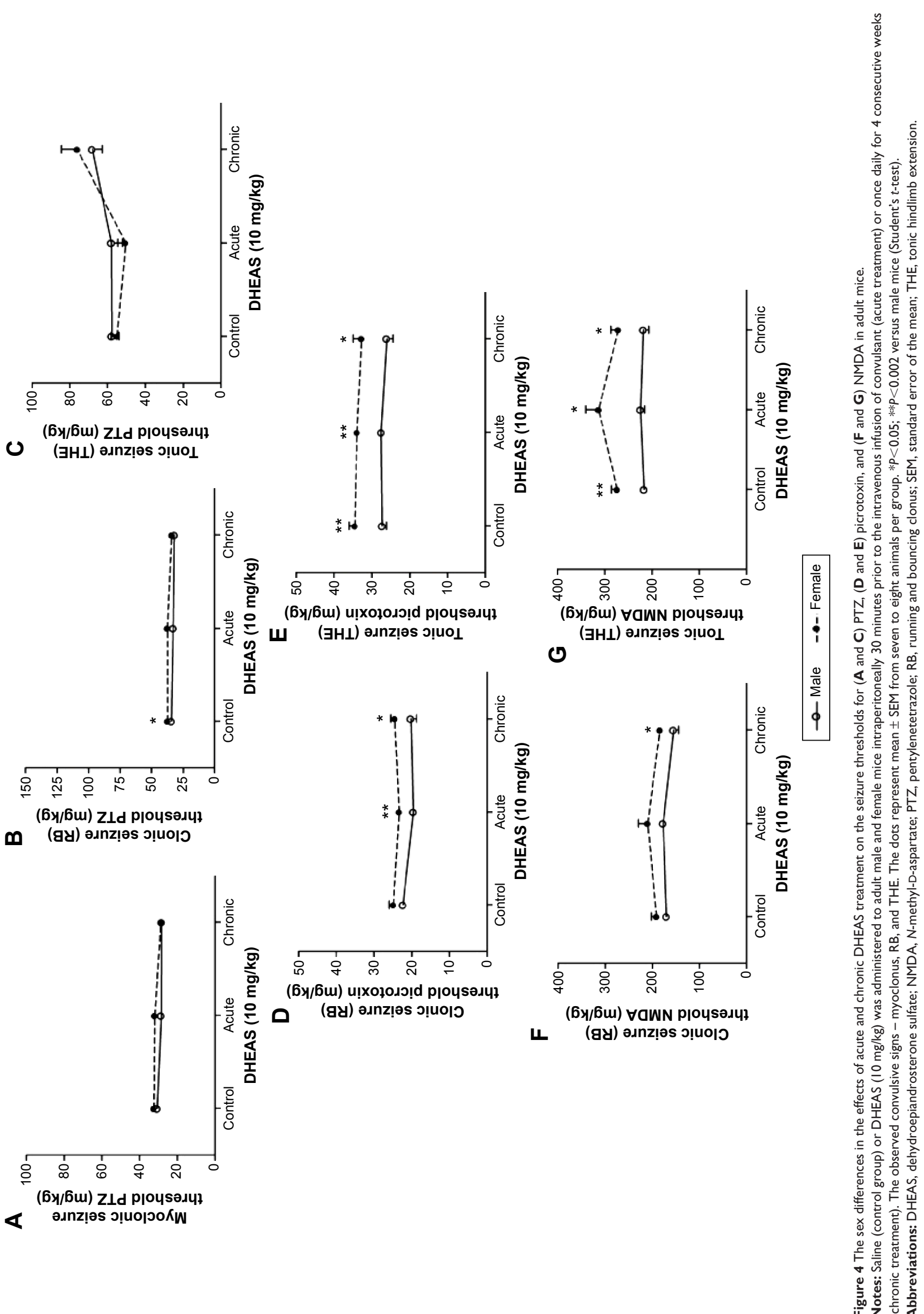
Table 2 The sex and age differences in the effects of acute DHEAS treatment on the seizure thresholds for picrotoxin in mice

\begin{tabular}{lll}
\hline $\begin{array}{l}\text { Seizure threshold } \\
\text { picrotoxin }(\mathbf{m g} / \mathbf{k g})\end{array}$ & RB & THE \\
\hline Adult control male mice & & $28.28 \pm 0.98$ \\
Adult control female mice & $21.88 \pm 0.76$ & $35.63 \pm 1.69$ \\
Adult DHEAS-treated male mice $(10 \mathrm{mg} / \mathrm{kg})$ & $25.62 \pm 1.62$ & $27.50 \pm 0.91$ \\
Adult DHEAS-treated female mice $(10 \mathrm{mg} / \mathrm{kg})$ & $19.59 \pm 0.41$ & $33.89 \pm 0.94$ \\
Aged control male mice & $23.32 \pm 0.79$ & $26.56 \pm 2.37$ \\
Aged control female mice & $16.33 \pm 0.47^{* *}$ & $26.76 \pm 0.74^{* * *}$ \\
Aged DHEAS-treated male mice $(10 \mathrm{mg} / \mathrm{kg})$ & $12.79 \pm 0.53^{\psi * * * *}$ & $22.34 \pm 3.76$ \\
Aged DHEAS-treated female mice $(10 \mathrm{mg} / \mathrm{kg})$ & $14.38 \pm 0.58^{* * *}$ & $27.40 \pm 1.88^{* *}$ \\
\hline
\end{tabular}

Notes: Saline (control group) or $10 \mathrm{mg} / \mathrm{kg}$ of DHEAS were administered intraperitoneally to adult and aged mice of both sexes, 30 minutes prior to the intravenous infusion of picrotoxin. The observed convulsive signs $-\mathrm{RB}$ and THE. The values represent mean \pm SEM from seven animals per group. ${ }^{\psi} P<0.02$ aged control female versus male mice; $* * P<0.01 ; * * * P<0.0004$ adult versus aged mice of the same sex and group (Student's $t$-test).

Abbreviations: DHEAS, dehydroepiandrosterone sulfate; RB, running and bouncing clonus; SEM, standard error of the mean; THE, tonic hindlimb extension.

\section{The effects of DHEAS treatment on the body weight}

Following determination of animal body weight, saline or $10 \mathrm{mg} / \mathrm{kg}$ DHEAS was administered ip to male and female mice once daily for 4 consecutive weeks. As expected, the male mice had a higher body weight than female mice both in control- and DHEAS-treated groups $(P<0.001$, ANOVA followed by Newman-Keuls test), on the first day as well as on the last day of the chronic treatment (Table 5). Animals in all groups gained body weight after 4 weeks of treatment, but only the body weight of DHEAS-treated female mice was significantly higher on the last day when compared to the first day of the treatment $(P<0.05$, ANOVA followed by Newman-Keuls test). However, as shown in Table 5, there were no differences in the body weight between control- and DHEAS-treated groups of both male and female mice, on the first day as well as on the last day of treatment.

Table 3 The effects of acute and chronic DHEAS treatment on locomotor activity of adult male and female mice

\begin{tabular}{|c|c|c|}
\hline $\begin{array}{l}\text { Locomotor activity } \\
\text { (counts/10 min) }\end{array}$ & $\begin{array}{l}\text { Acute } \\
(10 \mathrm{mg} / \mathrm{kg}) \\
\text { DHEAS } \\
\text { treatment }\end{array}$ & $\begin{array}{l}\text { Chronic } \\
(10 \mathrm{mg} / \mathrm{kg}) \\
\text { DHEAS } \\
\text { treatment }\end{array}$ \\
\hline Control male mice & $536.00 \pm 30.99$ & $522.50 \pm 27.45$ \\
\hline Control female mice & $592.00 \pm 19.52$ & $575.00 \pm 35.72$ \\
\hline DHEAS-treated male mice & $614.00 \pm 24.24$ & $587.40 \pm 30.30$ \\
\hline DHEAS-treated female mice & $622.10 \pm 26.35$ & $644.30 \pm 25.02$ \\
\hline
\end{tabular}

Notes: The locomotor activity of adult male and female mice was recorded for 10 minutes in the test cage, 30 minutes following single (acute treatment) or the last (after 4 consecutive weeks of chronic treatment) DHEAS $(10 \mathrm{mg} / \mathrm{kg})$ or saline intraperitoneal administration. The values represent mean \pm SEM from seven to eight animals per group.

Abbreviations: DHEAS, dehydroepiandrosterone sulfate; min, minutes; SEM, standard error of the mean.

\section{The effects of DHEAS treatment on the $\left[{ }^{3} \mathrm{H}\right]$ flunitrazepam binding to the brain membranes}

DHEAS inhibited the binding of $\left[{ }^{3} \mathrm{H}\right]$ flunitrazepam to the brain membranes isolated from both saline- and DHEAS-treated adult male and female mice in a concentration-dependent manner (Figure 5). The inhibitory potency of DHEAS (the half-maximum inhibition value) was in the micromolar range, maximum inhibition obtained with DHEAS was approximately $70 \%$, and slope factor was near unity in all investigated groups. As shown in Table 6, there were no significant differences in the maximum inhibition and half-maximum inhibition of $\left[{ }^{3} \mathrm{H}\right]$ flunitrazepam binding by DHEAS between saline- and DHEAS-treated adult male and female mice.

\section{Discussion}

This study demonstrated no differences in the body weight between control- and DHEAS-treated groups of both male and female mice. Our findings are in line with some previous animal studies reporting that acute and chronic administration of DHEAS has not affected body weight gain and food intake. ${ }^{43,44}$ On the other hand, our results are in contrast with the decrease in the body weight of mice observed following chronic DHEAS treatment, which the authors found to be consistent with reported proconvulsive, anxiogenic, provoking, as well as hypophagic effects of DHEAS. ${ }^{34,35,61,62}$ The same authors have also shown that DHEAS (1 and $2 \mathrm{mg} / \mathrm{kg}$ ) increased the motor activity in mice. ${ }^{34}$ However, in the present study and some other studies, locomotor activity, general ambulation, and motor coordination of animals were not affected by DHEAS treatment. ${ }^{37,42,45}$ Hence, as the present study has not provided experimental evidence on the provoking and proconvulsant effects of long-term DHEAS 
Table 4 The effects of acute and chronic DHEAS treatment on motor coordination of adult male and female CBA mice

\begin{tabular}{|c|c|c|c|c|}
\hline \multirow[t]{2}{*}{ Motor coordination } & \multicolumn{2}{|c|}{$\begin{array}{l}\text { Acute }(10 \mathrm{mg} / \mathrm{kg}) \\
\text { DHEAS treatment }\end{array}$} & \multicolumn{2}{|c|}{$\begin{array}{l}\text { Chronic }(10 \mathrm{mg} / \mathrm{kg}) \\
\text { DHEAS treatment }\end{array}$} \\
\hline & $\begin{array}{l}\text { The number } \\
\text { of falls }\end{array}$ & $\begin{array}{l}\text { The latency to } \\
\text { fall (seconds) }\end{array}$ & $\begin{array}{l}\text { The number } \\
\text { of falls }\end{array}$ & $\begin{array}{l}\text { The latency to } \\
\text { fall (seconds) }\end{array}$ \\
\hline Control male mice & $0.22 \pm 0.15$ & $106.70 \pm 8.82$ & $0.56 \pm 0.29$ & $95.56 \pm 12.37$ \\
\hline Control female mice & $0.50 \pm 0.50$ & $108.80 \pm 11.25$ & $0.78 \pm 0.22$ & $77.78 \pm 10.77$ \\
\hline DHEAS-treated male mice & $0.50 \pm 0.27$ & $95.00 \pm 12.39$ & $0.33 \pm 0.24$ & $104.40 \pm 10.42$ \\
\hline DHEAS-treated female mice & $0.33 \pm 0.17$ & $93.33 \pm 10.54$ & $0.25 \pm 0.25$ & $102.20 \pm 11.76$ \\
\hline
\end{tabular}

Notes: The pretrained adult male and female mice were placed on the rota-rod treadmill (constant speed of 15 rpm) 30 minutes following single (acute treatment) or the last (after 4 consecutive weeks of chronic treatment) DHEAS (10 mg/kg) or saline intraperitoneal administration. The number of falls and latency to fall was measured for up to 2 minutes. The values represent mean \pm SEM from seven to eight animals per group.

Abbreviations: DHEAS, dehydroepiandrosterone sulfate; SEM, standard error of the mean.

administration, perhaps it is not surprising that no changes in animal weight were observed as well.

Namely, our results demonstrated that both acute and chronic DHEAS treatments have not modified the seizure reactivity of mice to PTZ, picrotoxin, or NMDA, widely used convulsants in animal seizure models. These results are in agreement with studies in which DHEAS displayed neither proconvulsant nor anticonvulsant effects. For instance, DHEAS administered to mice in the doses from 1 to $40 \mathrm{mg} / \mathrm{kg}$ did not have any effects against acutely PTZ-induced or kindled convulsions or on the development of PTZ seizures. ${ }^{39}$ DHEAS ( 25 and $50 \mathrm{mg} / \mathrm{kg}$ ) also demonstrated no effect on kainate-induced convulsions, but elevated the kainate-induced lethality in mice. ${ }^{41}$ In line with our results, ip administration of DHEAS in doses of $12.5,50$, and $100 \mathrm{mg} / \mathrm{kg}$ showed no effect on the NMDAinduced seizures. ${ }^{37}$ On the other hand, $25 \mathrm{mg} / \mathrm{kg}$ of DHEAS significantly increased the dose of NMDA necessary to induce clonic convulsions in $50 \%$ of the tested mice, suggesting protective effect of DHEAS against NMDA-induced

Table 5 The effects of chronic DHEAS treatment on the body weight of adult male and female mice

\begin{tabular}{lll}
\hline Body weight (g) & $\begin{array}{l}\text { First day of } \\
\text { the treatment }\end{array}$ & $\begin{array}{l}\text { Last day of } \\
\text { the treatment }\end{array}$ \\
\hline Control male mice & $24.08 \pm 0.45^{*}$ & $24.90 \pm 0.76^{*}$ \\
Control female mice & $19.28 \pm 0.38$ & $21.22 \pm 0.63$ \\
DHEAS-treated male mice & $23.72 \pm 0.40^{*}$ & $25.45 \pm 0.30^{*}$ \\
DHEAS-treated female mice & $18.64 \pm 0.33$ & $21.06 \pm 0.76^{*}$ \\
\hline
\end{tabular}

Notes: Saline or DHEAS $(10 \mathrm{mg} / \mathrm{kg})$ was administered intraperitoneally to adult mice once daily for 4 consecutive weeks. The body weight of adult male and female animals was determined on the first and the last days of treatment. The values represent mean \pm SEM from seven to eight animals per group. $* P<0.00$ I, group of male mice versus corresponding group of female mice; $\Psi P<0.05$, DHEAS-treated female mice last day versus first day of the treatment (analysis of variance followed by Newman-Keuls test).

Abbreviations: DHEAS, dehydroepiandrosterone sulfate; SEM, standard error of the mean. seizures.$^{37}$ Previously, DHEAS was also shown to protect, both in vitro and in vivo, hippocampal neurons against excitatory amino acids-induced toxicity ${ }^{63}$ Moreover, DHEAS $(20 \mathrm{mg} / \mathrm{kg})$ administered daily with $45 \mathrm{mg} / \mathrm{kg}$ of cocaine for 12 days decreased the number of mice exhibiting cocaineinduced convulsions. ${ }^{40}$

In contrast to these results are the reports suggesting that DHEAS can induce seizures when administered systemically or directly into the brain. ${ }^{35,36}$ Namely, it has been shown that intracerebroventricular injection of DHEAS-induced clonictonic convulsions in mice in a dose-dependent manner. ${ }^{36}$ Moreover, Reddy and Kulkarni ${ }^{35}$ reported that although acute DHEAS treatment did not demonstrate proconvulsant effects, mice treated for 4 weeks with $10 \mathrm{mg} / \mathrm{kg}$ DHEAS exhibited increased seizure sensitivity to PTZ. The results are also contradictory in human studies. While some studies demonstrated high levels of DHEAS in female patients with epilepsy, ${ }^{64}$ other authors reported that women with more frequent seizures had an increase of cortisol and a decrease of DHEAS levels. ${ }^{38}$

The reasons for such discrepancies are not clear, but are usually explained by differences in the experimental approach or protocol, such as the solvent applied, seizure model, route of drug administration, administered dose, time of neurosteroid administration, as well as species or even animal strains used. For instance, unlike Reddy and Kulkarni ${ }^{35}$ who induced PTZ seizures in mice by a single ip injection, in our study, convulsions were induced by iv infusion of PTZ. PTZ infusion test is described as a sensitive model that allows determination of drug effects on separate components of seizure behavior and has been suggested for laboratory evaluation of anticonvulsant drugs. ${ }^{65,66}$ It is generally accepted that both PTZ and picrotoxin act as noncompetitive antagonists via picrotoxin site of the $\mathrm{GABA}_{\mathrm{A}}$ receptor, ${ }^{67,68}$ although Huang et a ${ }^{69}$ suggested that these two 
A

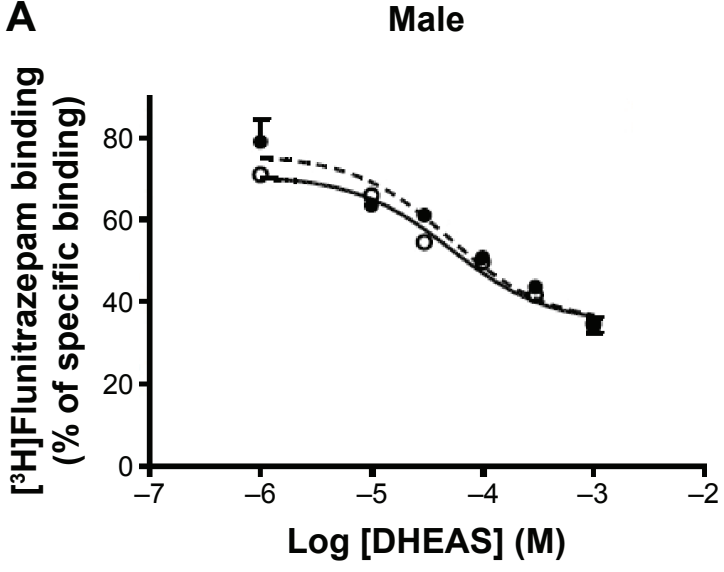

B

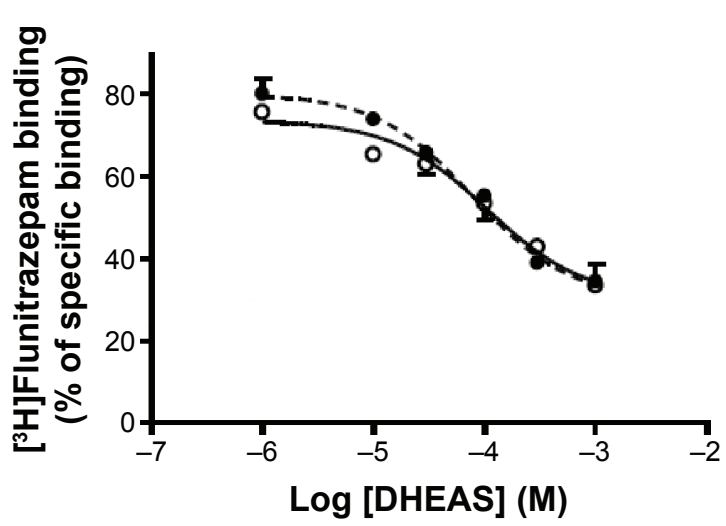

- Control $10 \mathrm{mg} / \mathrm{kg}$ DHEAS

Figure 5 The effects of acute DHEAS treatment on DHEAS-produced inhibition of $\left[{ }^{3} \mathrm{H}\right]$ flunitrazepam binding to the brain membranes of adult male and female mice. Notes: The animals were sacrificed 30 minutes following intraperitoneal administration of $10 \mathrm{mg} / \mathrm{kg}$ DHEAS or saline. Isolated brain membranes were incubated with increasing concentrations of DHEAS $\left(I \mu M\right.$ to I mM) and fixed concentration $(I \mathrm{nM})$ of $\left[{ }^{3} \mathrm{H}\right]$ flunitrazepam. Radioactivity bound to membranes after vacuum filtration was measured using $\beta$-scintillation counter. Nonspecific binding was determined in the presence of $100 \mu M$ diazepam. The inhibition curves were analyzed, and values of halfmaximum and maximum inhibition of $\left[{ }^{3} \mathrm{H}\right]$ flunitrazepam binding produced by DHEAS were determined. The dots represent mean $\pm \mathrm{SEM}$ from three independent experiments performed in duplicate.

Abbreviations: DHEAS, dehydroepiandrosterone sulfate; SEM, standard error of the mean.

convulsants interact with overlapping but distinct domains of the $\mathrm{GABA}_{\mathrm{A}}$ receptor.

As DHEAS has been also reported as an allosteric antagonist of $\mathrm{GABA}_{\mathrm{A}}$ receptor, ${ }^{26,27,30}$ which binds at or near the picrotoxin/t-butylbicyclophosphorothionate site on the $\mathrm{GABA}_{\mathrm{A}}$ receptor complex, ${ }^{70}$ it is possible that DHEAS competes with PTZ and picrotoxin for the same binding site or displaces their binding by steric hindrance. Such an interaction would explain why proconvulsive effects of DHEAS were not observed in PTZ- and picrotoxin-induced seizures. The interaction of DHEAS with excitatory amino acid transmission also seems rather complex. ${ }^{37}$ In line with

Table 6 The effects of acute DHEAS treatment on the potency of DHEAS for inhibiting $\left[{ }^{3} \mathrm{H}\right]$ flunitrazepam binding to the brain membranes of adult male and female mice

\begin{tabular}{lll}
\hline $\begin{array}{l}\text { DHEAS inhibition of } \\
\left.{ }^{3} \mathrm{H}\right] \text { flunitrazepam biding }\end{array}$ & $\mathrm{IC}_{50}(\mu \mathrm{M})$ & $I_{\max }(\%)$ \\
\hline Control male mice & $53.8 \pm 10.0$ & $65.66 \pm 1.59$ \\
Control female mice & $102.1 \pm 28.0$ & $65.56 \pm 4.35$ \\
DHEAS-treated male mice & $60.8 \pm 34.8$ & $69.60 \pm 1.56$ \\
DHEAS-treated female mice & $89.2 \pm 47.4$ & $70.93 \pm 6.04$ \\
\hline
\end{tabular}

Notes: The animals were sacrificed $30 \mathrm{~min}$ following the intraperitoneal administration of $10 \mathrm{mg} / \mathrm{kg}$ DHEAS or saline. Isolated brain membranes were incubated with increasing concentrations of DHEAS (I $\mu \mathrm{M}$ to I $\mathrm{mM}$ ) and fixed concentration ( $\mathrm{I} \mathrm{nM})$ of $\left[{ }^{3} \mathrm{H}\right]$ flunitrazepam. Nonspecific binding was determined in the presence of $100 \mu \mathrm{M}$ diazepam. The inhibition curves were analyzed, and the values of half-maximum $\left(\mathrm{IC}_{50}\right)$ and maximum $\left(I_{\max }\right)$ inhibition of $\left[{ }^{3} \mathrm{H}\right]$ flunitrazepam binding produced by DHEAS were determined. The values represent mean \pm SEM from three independent experiments performed in duplicate.

Abbreviations: DHEAS, dehydroepiandrosterone sulfate; $I_{50}$, half-maximum inhibition; min, minutes; SEM, standard error of the mean. our results, demonstrating that NMDA-induced seizures were not affected by chronic DHEAS treatment, some authors failed to detect significant effects of DHEAS on glutamate binding sites and glutamate uptake. ${ }^{71}$

The presence of sex differences in the sensitivity to GABA-related convulsants also seems to depend on the convulsive drug and methodology used to inject it. ${ }^{52}$ However, various results have been reported even when using convulsants that share the same receptor binding site. In contrast to the study demonstrating that PTZ, which acts via picrotoxin binding site, affects more female than male mice, ${ }^{52}$ Pericic et al observed higher picrotoxin sensitivity in male than in female mice. ${ }^{72}$ Even the same route of drug administration has not presented consistent results. For instance, intravenously injected bicuculline has been reported to affect more females ${ }^{73}$ or males ${ }^{72,74}$ or to have the same effect on both sexes. ${ }^{75}$ Moreover, regarding intravenously administered PTZ, Kokka et al ${ }^{76}$ demonstrated that male rats were more susceptible than females, while Finn and Gee ${ }^{73}$ found no seizure differences between sexes.

The discrepancy in the results might also be due to the differences in the stages of the female estrous cycle. Although the estrus cycle in our study was presumably synchronized due to the Whitten effect, we have not controlled the stage of the estrous cycle between experiments. As the estrous cycle is short, a variation of the estrous stages between different experiments is possible and might influence the effect of DHEAS on neuronal excitability of female 
mice. Different stages in the estrus cycle might be the reason why in our study sex differences were not always significant. However, male adult mice generally demonstrated lower thresholds for seizures induced by all three convulsants, when compared to female adult mice, regardless of whether they were acutely or chronically treated with DHEAS or treated with saline.

In contrast, in aged mice, we observed significant sex differences only in the control group, with female mice showing lower threshold for clonic picrotoxin-induced seizures. In line with our results, Zhang et $\mathrm{al}^{77}$ comparing adult and aged male and female mice following kainic acid treatment found that aged female mice demonstrated more severe seizure activity. On the other hand, our findings demonstrating sex differences in the susceptibility to tonic picrotoxin-induced convulsions only in adult but not in aged CBA mice are in line with a study reporting that unlike adult mice, 2-year- old CBA mice fail to display sex differences following picrotoxin administration. ${ }^{78}$ Nevertheless, since aged mice were not submitted to all experimental procedures as adult mice, our limited results regarding differences in neuronal excitability of aged male and female mice should be taken with caution.

In our study, the aged mice of both sexes demonstrated higher seizure sensitivity to picrotoxin when compared to adult mice, regardless of whether they were acutely treated with DHEAS or not. These results are in line with various findings demonstrating that aging is associated with an increased risk of seizures/epilepsy. ${ }^{79,80}$ It has been shown that aged rats exhibit altered EEG activity and clinical manifestations during kainate-induced status epilepticus. ${ }^{81}$ In addition, increased hippocampal excitability has been found in aged mice suggesting its relevance to the increased seizure susceptibility observed in aged subjects. ${ }^{82}$ However, different studies have reported both increased or decreased seizure susceptibility associated with advanced age, depending on the model and animal strain used. ${ }^{83}$

Following DHEAS administration, we determined some discrete but significant changes regarding sex differences in the susceptibility to clonic seizures in comparison to control groups. Because DHEA and its sulfate ester DHEAS serve as precursors for both androgenic and estrogenic steroids, ${ }^{1,84,85}$ some effects of DHEAS may be attributable to its conversion into these sexual hormones. ${ }^{53}$ Baulieu et $\mathrm{al}^{86}$ reported that following long-term DHEA administration to elderly men and women, in addition to the higher concentration of DHEAS, a small increase of testosterone and estradiol was noted, particularly in women, which may be involved in the observed beneficial physiological-clinical manifestations. Moreover, it has been suggested that both DHEA and DHEAS might have either estrogen- or androgen-like effects depending on the hormonal environment and thus influence the receptor type with which these neurosteroids interact. ${ }^{87}$ The suggestion of such interaction between DHEAS and male or female hormonal milieu is in line with previously reported sex-related differences in the DHEAS serum/plasma levels. ${ }^{54,88-90}$

Hence, the small changes regarding sex differences in the seizure sensitivity, observed following DHEAS treatment, could be explained by different modulation of the neurotransmitter receptor activity by DHEAS-derived sexual hormones and their metabolites. However, our findings showing that acute DHEAS treatment has not modified the potency of DHEAS to inhibit $\left[{ }^{3} \mathrm{H}\right]$ flunitrazepam binding on the brain membranes of adult male and female mice do not support this hypothesis, although they confirm previous results, which demonstrated that DHEAS behaves as an allosteric antagonist of the $\mathrm{GABA}_{\mathrm{A}}$ receptor. ${ }^{25-30}$ Further studies are needed in order to elucidate the role of GABAergic and other neurotransmitter systems in the complex effects of DHEAS on neuronal excitability.

The limitations of this study are a lack of lower doses of DHEAS ( 1 and $2 \mathrm{mg} / \mathrm{kg}$ ), which have been also shown to be active in mice, a lack of control for the stage of the mice estrous cycle between experiments, as well as the fact that aged mice were not submitted to all experimental procedures as adult mice.

\section{Conclusion}

Our findings demonstrating that DHEAS does not modify the locomotor activity, motor coordination, seizure susceptibility, brain $\left[{ }^{3} \mathrm{H}\right]$ flunitrazepam binding, and body weight in the mice of both sexes suggest that DHEAS treatment might be safe for various potential therapeutic applications in both adult and aged population. The results of our study also suggest discrete interaction of DHEAS with male and female hormonal status, which may underline observed sex-related differences in the association of DHEAS with various indicators of health and morbidity, although the underlying molecular mechanisms are not clear.

\section{Acknowledgments}

This work was supported by Croatian Ministry of Science, Education and Sport and International Brain Research Organization (IBRO). The skillful technical assistance of Zlatica Tonsetic, Jasminka Golubic Talic, and Goran Goles is gratefully acknowledged. The abstract of this paper was presented at the 7 th Croatian Congress of Pharmacology 
Zagreb, Croatia, September 18-21, 2013, as a poster presentation with interim findings. The abstract of the poster was published in "Poster Abstracts" in Periodicum Biologorum Vol 115, Suppl 3. Vitale, Branko (ed.), Zagreb, Croatian Society for Natural Sciences, Rudjer Boskovic Institute, LASERplus, 2013. 96-96.

\section{Disclosure}

The authors report no conflicts of interest in this work.

\section{References}

1. Friess E, Schiffelholz T, Steckler T, Steiger A. Dehydroepiandrosteronea neurosteroid. Eur J Clin Invest. 2000;30:46-50.

2. Maninger N, Wolkowitz OM, Reus VI, Epel ES, Mellon SH. Neurobiological and neuropsychiatric effects of dehydroepiandrosterone (DHEA) and DHEA sulfate (DHEAS). Front Neuroendocrinol. 2009; 30:65-91.

3. Pérez-Neri I, Montes S, Ojeda-López C, Ramírez-Bermúdez J, Ríos C. Modulation of neurotransmitter systems by dehydroepiandrosterone and dehydroepiandrosterone sulfate: mechanism of action and relevance to psychiatric disorders. Prog Neuropsychopharmacol Biol Psychiatry. 2008;32:1118-1130

4. Dong Y, Zheng P. Dehydroepiandrosterone sulphate: action and mechanism in the brain. J Neuroendocrinol. 2012;24:215-224.

5. Bologa L, Sharma J, Roberts E. Dehydroepiandrosterone and its sulfated derivative reduce neuronal death and enhance astrocytic differentiation in brain cell cultures. J Neurosci Res. 1987;17:225-234.

6. Kurata K, Takebayashi M, Morinobu S, Yamawaki S. Beta-estradiol, dehydroepiandrosterone, and dehydroepiandrosterone sulfate protect against N-methyl-D-aspartate-induced neurotoxicity in rat hippocampal neurons by different mechanisms. J Pharmacol Exp Ther. 2004;311: 237-245.

7. Lapchak PA, Chapman DF, Nunez SY, Zivin JA. Dehydroepiandrosterone sulfate is neuroprotective in a reversible spinal cord ischemia model: possible involvement of GABA(A) receptors. Stroke. 2000;31 1953-1956.

8. Zhang L, Li BS, Ma W, et al. Dehydroepiandrosterone (DHEA) and its sulfated derivative (DHEAS) regulate apoptosis during neurogenesis by triggering the Akt signaling pathway in opposing ways. Brain Res Mol Brain Res. 2002;98:58-66.

9. Taylor MK, Stone M, Laurent HK, Rauh MJ, Granger DA. Neuroprotective-neurotrophic effect of endogenous dehydroepiandrosterone sulfate during intense stress exposure. Steroids. 2014;87:54-58.

10. de Bruin VM, Vieira MC, Rocha MN, Viana GS. Cortisol and dehydroepiandosterone sulfate plasma levels and their relationship to aging, cognitive function, and dementia. Brain Cogn. 2002;50:316-323.

11. Flood JF, Morley JE, Roberts E. Pregnenolone sulfate enhances posttraining memory processes when injected in very low doses into limbic system structures: the amygdala is by far the most sensitive. Proc Natl Acad Sci U S A. 1995;92:10806-10810.

12. Maurice T, Lockhart BP. Neuroprotective and anti-amnesic potentials of sigma (sigma) receptor ligands. Prog Neuropsychopharmacol Biol Psychiatry. 1997;21:69-102.

13. Milman A, Zohar O, Maayan R, Weizman R, Pick CG. DHEAS repeated treatment improves cognitive and behavioral deficits after mild traumatic brain injury. Eur Neuropsychopharmacol. 2008;18: 181-187.

14. Nicolas LB, Pinoteau W, Papot S, Routier S, Guillaumet G, Mortaud S. Aggressive behavior induced by the steroid sulfatase inhibitor COUMATE and by DHEAS in CBA/H mice. Brain Res. 2001;922:216-222.

15. Wolf OT, Kirschbaum C. Actions of dehydroepiandrosterone and its sulfate in the central nervous system: effects on cognition and emotion in animals and humans. Brain Res Brain Res Rev. 1999;30:264-288.
16. Assies J, Visser I, Nicolson NA, et al. Elevated salivary dehydroepiandrosterone-sulfate but normal cortisol levels in medicated depressed patients: preliminary findings. Psychiatry Res. 2004;128: $117-122$.

17. Buydens-Branchey L, Branchey M, Hudson J, Majewska DM. Perturbations of plasma cortisol and DHEA-S following discontinuation of cocaine use in cocaine addicts. Psychoneuroendocrinology. 2002;27: 83-97.

18. Hillen T, Lun A, Reischies FM, Borchelt M, Steinhagen-Thiessen E, Schaub RT. DHEA-S plasma levels and incidence of Alzheimer's disease. Biol Psychiatry. 2000;47:161-163.

19. Söndergaard HP, Hansson LO, Theorell T. Elevated blood levels of dehydroepiandrosterone sulphate vary with symptom load in posttraumatic stress disorder: findings from a longitudinal study of refugees in Sweden. Psychother Psychosom. 2002;71:298-303.

20. Strous RD, Maayan R, Lapidus R, et al. Increased circulatory dehydroepiandrosterone and dehydroepiandrosterone-sulphate in first-episode schizophrenia: relationship to gender, aggression and symptomatology. Schizophr Res. 2004;71:427-434.

21. Rupprecht R. Neuroactive steroids: mechanisms of action and neuropsychopharmacological properties. Psychoneuroendocrinology. 2003;28:139-168.

22. Stárka L, Dušková M, Hill M. Dehydroepiandrosterone: a neuroactive steroid. J Steroid Biochem Mol Biol. 2015;145:254-260.

23. Hill M, Dušková M, Stárka L. Dehydroepiandrosterone, its metabolites and ion channels. J Steroid Biochem Mol Biol. 2015;145:293-314.

24. Majewska MD. Neurosteroids: endogenous bimodal modulators of the $\mathrm{GABA}_{\mathrm{A}}$ receptor. Mechanism of action and physiological significance. Prog Neurobiol. 1992;38:379-395.

25. Baulieu EE, Robel P. Dehydroepiandrosterone (DHEA) and dehydroepiandrosterone sulfate (DHEAS) as neuroactive neurosteroids. Proc Natl Acad Sci U S A. 1998;95:4089-4091.

26. Demirgören S, Majewska MD, Spivak CE, London ED. Receptor binding and electrophysiological effects of dehydroepiandrosterone sulfate, an antagonist of the GABA A receptor. Neuroscience. 1991;45: $127-135$.

27. Majewska MD, Demirgören S, Spivak CE, London ED. The neurosteroid dehydroepiandrosterone sulfate is an allosteric antagonist of the GABA receptor. Brain Res. 1990;526:143-146.

28. Lambert JJ, Belelli D, Peden DR, Vardy AW, Peters JA. Neurosteroid modulation of GABA receptors. Prog Neurobiol. 2003;71:67-80.

29. Shen W, Mennerick S, Zorumski EC, Covey DF, Zorumski CF. Pregnenolone sulfate and dehydroepiandrosterone sulfate inhibit GABA-gated chloride currents in Xenopus oocytes expressing picrotoxininsensitive GABA(A) receptors. Neuropharmacology. 1999;38: 267-271.

30. Svob Strac D, Jazvinscak Jembrek M, Erhardt J, Mirkovic Kos K, Pericic D. Modulation of recombinant GABA(A) receptors by neurosteroid dehydroepiandrosterone sulfate. Pharmacology. 2012;89: 163-171.

31. Irwin RP, Lin SZ, Rogawski MA, Purdy RH, Paul SM. Steroid potentiation and inhibition of N-methyl-D-aspartate receptor-mediated intracellular $\mathrm{Ca}^{++}$responses: structure-activity studies. $J$ Pharmacol Exp Ther. 1994;271:677-682.

32. Maurice T, Roman FJ, Privat A. Modulation by neurosteroids of the in vivo $(+)-\left[{ }^{3} \mathrm{H}\right] \mathrm{SKF}-10,047$ binding to sigma 1 receptors in the mouse forebrain. J Neurosci Res. 1996;46:734-743.

33. Carette B, Poulain P. Excitatory effect of dehydroepiandrosterone, its sulphate ester and pregnenolone sulphate, applied by iontophoresis and pressure, on single neurones in the septo-preoptic area of the guinea pig. Neurosci Lett. 1984;45:205-210.

34. Reddy DS, Kulkarni SK. Differential anxiolytic effects of neurosteroids in the mirrored chamber behavior test in mice. Brain Res. 1997; 752:61-71.

35. Reddy DS, Kulkarni SK. Proconvulsant effects of neurosteroids pregnenolone sulfate and dehydroepiandrosterone sulfate in mice. Eur $J$ Pharmacol. 1998;345:55-59. 
36. Członkowska AI, Krzaścik P, Sienkiewicz-Jarosz H, et al. The effects of neurosteroids on picrotoxin-, bicuculline- and NMDA-induced seizures, and a hypnotic effect of ethanol. Pharmacol Biochem Behav. 2000;67:345-353

37. Budziszewska B, Siwanowicz J, Leśkiewicz M, Jaworska-Feil L, Lasoń W. Protective effects of neurosteroids against NMDAinduced seizures and lethality in mice. Eur Neuropsychopharmacol. 1998;8:7-12.

38. Galimberti CA, Magri F, Copello F, et al. Seizure frequency and cortisol and dehydroepiandrosterone sulfate (DHEAS) levels in women with epilepsy receiving antiepileptic drug treatment. Epilepsia. 2005;46: 517-523.

39. Hansen SL, Sperling BB, Sánchez C. Anticonvulsant and antiepileptogenic effects of $\mathrm{GABA}_{\mathrm{A}}$ receptor ligands in pentylenetetrazolekindled mice. Prog Neuropsychopharmacol Biol Psychiatry. 2004;28: $105-113$.

40. Leśkiewicz M, Budziszewska B, Jaworska-Feil L, Kubera M, BastaKaim A, Lasoń W. Inhibitory effect of some neuroactive steroids on cocaine-induced kindling in mice. Pol J Pharmacol. 2003; 55:1131-1136.

41. Leśkiewicz M, Budziszewska B, Jaworska-Feil L, Lasoń W. Effects of neurosteroids on kainate-induced seizures, neurotoxicity and lethality in mice. Pol J Pharmacol. 1997;49:411-417.

42. Andrade S, Silveira SL, Gomez R, Barros HM, Ribeiro MF. Gender differences of acute and chronic administration of dehydroepiandrosterone in rats submitted to the forced swimming test. Prog Neuropsychopharmacol Biol Psychiatry. 2007;31:613-621.

43. Lea-Currie YR, Wen P, McIntosh MK. Dehydroepiandrosterone-sulfate (DHEAS) reduces adipocyte hyperplasia associated with feeding rats a high-fat diet. Int J Obes Relat Metab Disord. 1997;21:1058-1064.

44. Lea-Currie YR, Wu SM, McIntosh MK. Effects of acute administration of dehydroepiandrosterone-sulfate on adipose tissue mass and cellularity in male rats. Int J Obes Relat Metab Disord. 1997;21:147-154.

45. Zajda ME, Krzascik P, Hill M, Majewska MD. Psychomotor and rewarding properties of the neurosteroids dehydroepiandrosterone sulphate and androsterone: effects on monoamine and steroid metabolism. Acta Neurobiol Exp (Wars). 2012;72:65-79.

46. Dhatariya KK, Nair KS. Dehydroepiandrosterone: is there a role for replacement? Mayo Clin Proc. 2003;78:1257-1273.

47. Rainey WE, Nakamura Y. Regulation of the adrenal androgen biosynthesis. J Steroid Biochem Mol Biol. 2008;108:281-286.

48. Rutkowski K, Sowa P, Rutkowska-Talipska J, Kuryliszyn-Moskal A, Rutkowski R. Dehydroepiandrosterone (DHEA): hypes and hopes. Drugs. 2014;74:1195-1207.

49. Chen JR, Tseng GF, Wang YJ, Wang TJ. Exogenous dehydroisoandrosterone sulfate reverses the dendritic changes of the central neurons in aging male rats. Exp Gerontol. 2014;57:191-202.

50. Nawata H, Yanase T, Goto K, Okabe T, Ashida K. Mechanism of action of anti-aging DHEA-S and the replacement of DHEA-S. Mech Ageing Dev. 2002;123:1101-1106.

51. Leowattana W. DHEAS as a new diagnostic tool. Clin Chim Acta. 2004; 341:1-15.

52. Medina AE, Manhães AC, Schmidt SL. Sex differences in sensitivity to seizures elicited by pentylenetetrazol in mice. Pharmacol Biochem Behav. 2001;68:591-596.

53. Glei DA, Goldman N, Weinstein M, Liu IW. Dehydroepiandrosterone sulfate (DHEAS) and health: does the relationship differ by sex? Exp Gerontol. 2004;39:321-331.

54. Laughlin GA, Barrett-Connor E. Sexual dimorphism in the influence of advanced aging on adrenal hormone levels: the Rancho Bernardo Study. J Clin Endocrinol Metab. 2000;85:3561-3568.

55. Whitten WK, Bronson FH, Greenstein JA. Estrus-inducing pheromone of male mice: transport by movement of air. Science. 1968;161: 584-585.

56. Svec F, Porter JR. The actions of exogenous dehydroepiandrosterone in experimental animals and humans. Proc Soc Exp Biol Med. 1998; 218:174-191.
57. Finn DA, Crabbe JC. Chronic ethanol differentially alters susceptibility to chemically induced convulsions in withdrawal seizure-prone and -resistant mice. J Pharmacol Exp Ther. 1999;288:782-790.

58. Kosobud AE, Crabbe JC. Genetic correlations among inbred strain sensitivities to convulsions induced by 9 convulsant drugs. Brain Res. 1990;526:8-16.

59. Pericic D, Svob D, Jazvinscak M, Mirkovic K. Anticonvulsive effect of swim stress in mice. Pharmacol Biochem Behav. 2000;66:879-886.

60. Lowry OH, Rosebrough NJ, Farr AL, Randall RJ. Protein measurement with the folin phenol reagent. J Biol Chem. 1951;193:265-275.

61. Reddy DS, Kulkarni SK. The role of GABA-A and mitochondrial diazepam-binding inhibitor receptors on the effects of neurosteroids on food intake in mice. Psychopharmacology (Berl). 1998;137:391-400.

62. Reddy DS, Kulkarni SK. Sex and estrous cycle-dependent changes in neurosteroid and benzodiazepine effects on food consumption and plus-maze learning behaviors in rats. Pharmacol Biochem Behav. 1999; 62:53-60.

63. Kimonides VG, Khatibi NH, Svendsen CN, Sofroniew MV, Herbert J. Dehydroepiandrosterone (DHEA) and DHEA-sulfate (DHEAS) protect hippocampal neurons against excitatory amino acid-induced neurotoxicity. Proc Natl Acad Sci U S A. 1998;95:1852-1857.

64. El-Khayat HA, Abd El-Basset FZ, Tomoum HY, et al. Physical growth and endocrinal disorders during pubertal maturation in girls with epilepsy. Epilepsia. 2004;45:1106-1115.

65. Loscher W, Nolting B. The role of technical, biological and pharmacological factors in the laboratory evaluation of anticonvulsant drugs. IV. Protective indices. Epilepsy Res. 1991;9:1-10.

66. Mandhane SN, Aavula K, Rajamannar T. Timed pentylenetetrazol infusion test: a comparative analysis with s.c. PTZ and MES models of anticonvulsant screening in mice. Seizure. 2007;16:636-644.

67. Ramanjaneyulu R, Ticku MK. Interactions of pentamethylenetetrazole and tetrazole analogues with the picrotoxinin site of the benzodiazepineGABA receptor-ionophore complex. Eur J Pharmacol. 1984;98: 337-345.

68. Squires RF, Saederup E, Crawley JN, Skolnick P, Paul SM. Convulsant potencies of tetrazoles are highly correlated with actions on GABA/ benzodiazepine/picrotoxin receptor complexes in brain. Life Sci. 1984; 35:1439-1444.

69. Huang RQ, Bell-Horner CL, Dibas MI, Covey DF, Drewe JA, Dillon GH. Pentylenetetrazole-induced inhibition of recombinant gamma-aminobutyric acid type A (GABA(A)) receptors: mechanism and site of action. J Pharmacol Exp Ther. 2001;298:986-995.

70. Sousa A, Ticku MK. Interactions of the neurosteroid dehydroepiandrosterone sulfate with the GABA(A) receptor complex reveals that it may act via the picrotoxin site. J Pharmacol Exp Ther. 1997;282:827-833.

71. Leśkiewicz M, Budziszewska B, Jaworska-Feil L, Kajta M, Lasoń W. Effect of neurosteroids on glutamate binding sites and glutamate uptake in rat hippocampus. Pol J Pharmacol. 1998;50:355-360.

72. Pericic D, Manev H, Geber J. Sex related differences in the response of mice, rats and cats to administration of picrotoxin. Life Sci. 1986;38: 905-913.

73. Finn DA, Gee KW. The estrus cycle, sensitivity to convulsants and the anticonvulsant effect of a neuroactive steroid. J Pharmacol Exp Ther. 1994;271:164-170.

74. Guillet R, Dunham L. Neonatal caffeine exposure and seizure susceptibility in adult rats. Epilepsia. 1995;36:743-749.

75. Devaud LL, Purdy RH, Morrow AL. The neurosteroid, 3 alphahydroxy-5 alpha-pregnan-20-one, protects against bicuculline-induced seizures during ethanol withdrawal in rats. Alcohol Clin Exp Res. 1995; 19:350-355.

76. Kokka N, Sapp DW, Witte U, Olsen RW. Sex differences in sensitivity to pentylenetetrazole but not in $\mathrm{GABA}_{\mathrm{A}}$ receptor binding. Pharmacol Biochem Behav. 1992;43:441-447.

77. Zhang XM, Zhu SW, Duan RS, Mohammed AH, Winblad B, Zhu J. Gender differences in susceptibility to kainic acid-induced neurodegeneration in aged C57BL/6 mice. Neurotoxicology. 2008;29: 406-412. 
78. Manev H, Pericic D, Anic-Stojiljkovic S. Sex differences in the sensitivity of CBA mice to convulsions induced by GABA antagonists are age-dependent. Psychopharmacology (Berl). 1987;91:226-229.

79. Jetter GM, Cavazos JE. Epilepsy in the elderly. Semin Neurol. 2008;28: 336-341.

80. Brodie MJ, Elder AT, Kwan P. Epilepsy in later life. Lancet Neurol. 2009;8:1019-1030.

81. Darbin O, Naritoku D, Patrylo PR. Aging alters electroencephalographic and clinical manifestations of kainate-induced status epilepticus. Epilepsia. 2004;45:1219-1227.

82. El-Hayek YH, Wu C, Ye H, Wang J, Carlen PL, Zhang L. Hippocampal excitability is increased in aged mice. Exp Neurol. 2013;247:710-719.

83. Kelly KM. Aging models of acute seizures and epilepsy. Epilepsy Curr. 2010;10:15-20.

84. Arlt W, Callies F, Allolio B. DHEA replacement in women with adrenal insufficiency - pharmacokinetics, bioconversion and clinical effects on well-being, sexuality and cognition. Endocr Res. 2000;26:505-511.

85. Labrie F, Luu-The V, Labrie C, Simard J. DHEA and its transformation into androgens and estrogens in peripheral target tissues: intracrinology. Front Neuroendocrinol. 2001;22:185-212.
86. Baulieu EE, Thomas G, Legrain S, et al. Dehydroepiandrosterone (DHEA), DHEA sulfate, and aging: contribution of the DHEAge Study to a sociobiomedical issue. Proc Natl Acad Sci U S A. 2000;97:4279-4284.

87. Ebeling P, Koivisto VA. Physiological importance of dehydroepiandrosterone. Lancet. 1994;343:1479-1481.

88. Sulcová J, Hill M, Hampl R, Stárka L. Age and sex related differences in serum levels of unconjugated dehydroepiandrosterone and its sulphate in normal subjects. $J$ Endocrinol. 1997;154:57-62.

89. Young DG, Skibinski G, Mason JI, James K. The influence of age and gender on serum dehydroepiandrosterone sulphate (DHEA-S), IL-6, IL-6 soluble receptor (IL-6 sR) and transforming growth factor beta 1 (TGF-beta1) levels in normal healthy blood donors. Clin Exp Immunol. 1999; 117:476-481.

90. Zumoff BV, Bradlow HL. Sex difference in the metabolism of dehydroisoandrosterone sulfate. J Clin Endocrinol Metab. 1980;51: 334-336.

\section{Publish your work in this journal}

Drug Design, Development and Therapy is an international, peerreviewed open-access journal that spans the spectrum of drug design and development through to clinical applications. Clinical outcomes, patient safety, and programs for the development and effective, safe, and sustained use of medicines are a feature of the journal, which has also been accepted for indexing on PubMed Central. The manuscript management system is completely online and includes a very quick and fair peer-review system, which is all easy to use. Visit http://www.dovepress.com/testimonials.php to read real quotes from published authors.

Submit your manuscript here: http://www.dovepress.com/drug-design-development-and-therapy-journal 